Original article

DOI: $10.19027 /$ jai.21.1.1-10

\title{
Analysis of the use of media resulting from bioconversion of organic waste in the production of maggots BSF (black soldier fly)
}

\section{Analisis penggunaan media hasil biokonversi sampah organik pada produksi maggots BSF(black soldier fly)}

\author{
Syahrizal $^{1}$, Ediwarman $^{2}$, Safratilofa $^{3}$, Muhammad Ridwan $^{4}$ \\ ${ }^{1,3,4}$ Study Program of Aquaculture, Faculty of Agriculture, Batanghari University, \\ Jambi, Indonesia \\ ${ }^{2}$ Freshwater Aquaculture Fisheries Center (FAFC/BPBAT) Sungai Gelam Jambi, Indonesia \\ *Corresponding author: syahrizal@unbari.ac.id
}

(Received February 10, 2021; Accepted November 25, 2021)

\begin{abstract}
Maggots is an organism derived from the eggs of the black fly, Hermentia illucens (black soldier fly, BSF), which undergoes metamorphosis in the second phase after the egg phase and before the pupa phase which then turns into an adult fly. The purpose of this study was to analyze the utilization of organic waste substrate on the production of BSF maggots cultivation. This research was conducted outdoor at the Freshwater Aquaculture Fisheries Center (BPBAT) Sungai Gelam Jambi with a completely randomized design (CRD) with 4 treatments and 3 replications; Treatment A: PKM (palm kernel meal) 100\%, B (PKM 50\% + cabbage vegetable waste 50\%), C (PKM 50\% + coconut pulp 50\%) and D (PKM 50\% + coconut pulp 25\% + vegetable waste cabbage 25\%). The average yield parameter of high maggots biomass in treatment A was $673.67 \mathrm{~g} / 4 \mathrm{~kg}$ substrate and the lowest biomass in treatment D was $239.67 \mathrm{~g} / 4 \mathrm{~kg}$ substrate. For the average weight and length of the best maggots in treatment $\mathrm{A}(0.20 \mathrm{~g} /$ individual) and $(1.83 \mathrm{~cm})$, the lowest was in $\mathrm{B}(0.12 \mathrm{~g} / \mathrm{Ind}$. and $1.58 \mathrm{~cm})$. The highest was in treatment $\mathrm{B}(5,182.31$ individual $/ 4 \mathrm{~kg}$ substrate) and the lowest was in $\mathrm{D}(1,479.44 \mathrm{ind} . / 4 \mathrm{~kg}$ substrate. The highest bioconversion value of maggots to organic matter OSE (organic substrate efficiency) was highest in treatment A (16,84\%) and the lowest was in D (5.99\%). Technically, treatment A was slightly better than B, while economically the best organic substrate medium for maggots cultivation was in treatment B with a production cost of Rp. 7.257 and the ECR (economic conversion ratio) value of 5.81 was lower than the other 3 treatments.
\end{abstract}

Keywords: Maggots, black soldier fly, Hermentia illucens, organic waste.

\begin{abstract}
ABSTRAK
Maggots merupakan organisme yang berasal dari telur seranga lalat hitam, Hermentia illucens (black soldier fly, BSF). Tujuan penelitian ini yaitu menganalisis pemanfaatan subtrat limbah organik terhadap produksi budidaya maggots BSF. Penelitian ini dilaksanakan di Balai Perikanan Budidaya Air Tawar (BPBAT) Sungai Gelam, Jambi dengan rancangan acak lengkap (RAL) 4 perlakuan 3 ulangan yaitu perlakuan A : PKM (palm kernel meal) 100\%, B (PKM 50\% + limbah sayur kol 50\%), C (PKM 50\% + ampas kelapa 50\%), dan D (PKM 50\% + ampas kelapa $25 \%+$ limbah sayur kol 25\%). Rata-rata biomassa tertinggi didapatkan pada perlakuanA (673,67g/4 kg subtrat) dan biomassa terendah dihasilkan pada perlakuan $\mathrm{D}(239.67 \mathrm{~g} / 4 \mathrm{~kg}$ subtrat). Untuk bobot rata-rata dan panjang maggots terbaik dihasilkan pada perlakuan A ( $0,20 \mathrm{~g} /$ individu dan $1,83 \mathrm{~cm} / \mathrm{individu})$, terendah pada $\mathrm{B}(0,12 \mathrm{~g} /$ individu dan $(1,58 \mathrm{~cm})$. Jumlah populasi maggots yang terbanyak dihasilkan pada perlakuan B $(5 \cdot 182,31 \mathrm{ind} / 4 \mathrm{~kg}$ subtrat $)$ dan terendah pada D (1.479,44 individu/4 kg subtrat). Nilai biokonversi maggots terhadap bahan organik OSE terbaik (organic substrate efficiency) tertinggi pada perlakuan A (16,84\%) dan terendah pada D (5,99\%). Secara teknis perlakuan A sedikit lebih baik dari B sedangkan secara ekonomi media subtrat organik terbaik untuk budidaya maggots terdapat pada perlakuan B dengan biaya produksi sebesar Rp. 7.257 dan nilai ECR (economic convertion ratio) sebesar 5.81 lebih rendah dari ke 3 perlakuan lainnya.
\end{abstract}

Kata kunci: Maggots, black soldier fly, Hermentia illucens, limbah organik. 


\section{INTRODUCTION}

Feed is one of the most important in aquaculture. The availability of feed will affect the growth and survival of fish which can increase fish production. The price of commercial feed increases gradually due to the raw materials supply. Feed is the main component in aquaculture activities because it plays a major role in the cost aspect, approximately $50-75 \%$ of total production costs are generated from feed utilization so that the efficiency of using small amounts of a feed helps to reduce production costs and increase payback period (Adéyèmi et al., 2020). A payback period indicates a certain period to recover an investment cost (Fika et al., 2016; Izmaniar et al., 2018). The type of commercial feed is the main factor in the high cost of aquaculture production. The increasing price of a commercial decreases the income of farmers (Baki \& Yücel, 2017; Azhari et al., 2020). The use of local raw materials in the formulation of artificial feed can reduce feed costs. The utilization of organic waste as raw material for artificial feed can be applied to aquaculture, yet the composition of the organic content will reduce protein content in feed (Tugiyono et al., 2020; Cahya et al., 2021).

In addition to artificial feed formulations, organic waste was also used for the production of maggots as a natural feed for fish farming. Maggots production using organic waste could be done by composting or maggots bioconversion techniques (BSF). A 2-week maggots are ready to be used as feed (Mokolensang et al., 2018). Cicilia and Susila (2021) explained that the maggots given to cultured fish can be in the form of fresh maggots, crushed maggots, and it can also be used as raw material for making fish feed instead of fish meal. The bioconversion process aims to change the form of organic waste by insect larvae and convert it into biomass (Leong et al., 2016). The conversion of organic waste produces simpler forms through a biotransformation process with nutritional content consisting of polypeptides containing proteins, lipids, peptides, amino acids, chitin, and vitamins (Liu et al., 2019). Therefore, BSF maggots are potential non-pest insects as an important protein source for the $21^{\text {st }}$ century (Rui et al., 2017).

Maggots derived the pre-pupa stage has a high protein content (Herawati et al., 2020). Maggots in the form of flour has advantages compared to other artificial feed raw materials because it is rich in protein nutrients and amino acids, $40-50 \%$ of protein, and $30 \%$ of fat. The amino acid content consists of cysteine, histidine, tryptophan, and tyrosine (Cummins et al., 2017; Herawati et al., 2020). According to Fauzi and Sari (2018), maggots are a type of natural feed that has high protein containing $41-42 \%$ crude protein, 31-35\% ether extract, 14-15\% ash, $4.8-5.1 \%$ calcium, and $0.6-0.63 \%$ phosphorus in dry form. Arifin et al. (2020) explained that the use of maggots flour as a protein source in the formulation of tilapia feed can be substituted for $75 \%$ of fish meal. The body composition of BSF maggots larvae is highly dependent on the quality and quantity of food ingested (Nguyen $e t$ al., 2015).

In technical cultivation, BSF maggots need a substrate to live that serves as a food source for BSF maggots. To produce better maggots at a low cost, it can be done by engineering the type of organic medium substrate or improving the environment of the maggots medium itself. Several types of substrates have been used for the cultivation of BSF maggots, including coffee grounds (Lardé, 1990), manure (Newton et al., 2005), beet pulp, grains (Tschirner \& Simon, 2015), tofu pulp, bran, coconut pulp, oil palm meal, various fermented ingredients (Lestari et al., 2020), and its combination (Rizki et al., 2017). Fahmi et al. (2009) reported that BSF (black soldier fly) maggots larvae living in oil palm dregs were able to reduce organic waste by up to 56\%. In addition, Syahrizal et al. (2014) also reported that there was a difference in the production of maggots Hermetia illucens in the use of $100 \%$ palm kernel meal (PKM) (4 kg) with a combination of $1 \mathrm{~kg}$ PKM (25\%) and 3 $\mathrm{kg}$ of tofu dregs where $100 \%$ of PKM produced the highest maggots production of $1.66 \pm 0.13 \mathrm{~kg}$ (41.5\%) while the combination of $1 \mathrm{~kg}$ of PKM $(25 \%)$ and $3 \mathrm{~kg}$ of tofu dregs produced the lowest maggots production of $0.57 \pm 0.13 \mathrm{~kg}(14.25 \%)$.

The use of PKM as the main live medium has been proven to have resulted in high maggots production. However, this research still needs to be continued to increase the production of maggots with different combination materials and the use of PKM is not a monopoly or high dependence on this material. Therefore, the results of the research by Syahrizal et al. (2014) become the basis for the implementation of this research. In addition to the combination of PKM with other ingredients, information that is important to find is the amount or ratio of the use of PKM with the combined ingredients. This study aims to analyze the PKM 
organic waste medium and its combination of product performance and economic analysis.

\section{MATERIALS AND METHODS}

\section{Experimental design}

This research was conducted in May 2020 for 30 days at the Sungai Gelam, Jambi Freshwater Aquaculture Center. This study used a completely randomized design (CRD) with 4 treatments and 3 replications, i.e. treatment A : PKM 100\%, treatment B: $50 \% \mathrm{PKM}+50 \%$ cabbage vegetable waste $(\mathrm{CVW})$, treatment C: $50 \% \mathrm{PKM}+50 \%$ coconut meal $(\mathrm{CM})$, and treatment D: $50 \%$ $\mathrm{PKM}+25 \%$ coconut meal $(\mathrm{CM})+25 \%$ cabbage vegetable waste (CVW).

\section{Equipment and materials}

The used containers were 12 round plastic buckets with a diameter of $50 \mathrm{~cm}$ and all of them were covered with corrugated tin roofs. Then put the dried banana leaves on the substrates (as a medium for $H$. illucens flies to lay their eggs) as much as 3 pieces. The container was placed randomly at a predetermined location and the container was $20 \mathrm{~cm}$ high. The research site was fenced using a 1-meter high net.

\section{Research procedure}

The implementation of the maggots cultivation research experiment was carried out by placing the waste media material into a plastic bucket for each treatment. Then, $4 \mathrm{~L}$ of freshwater was added to the container as a solvent and stirred evenly. The top of each medium was covered with dry banana leaves. After that, each bucket is covered with corrugated plastic zinc so that flies can still enter the experimental bucket.

The live medium substrates maggots Hermetia illucens from black soldier fly (BSF) used as a treatment in the form of palm kernel meal, coconut waste, and proximate cabbage vegetable waste the results can be seen in Table 1. Substrate composition is the result of the initial analysis of the proximate profile of the media content that will be used in this study. The filter media materials in the treatment included oil palm waste, coconut waste, and cabbage vegetable waste. The composition of the proximate value of maggots growing media is also presented in Table 1.

\section{Data collection}

Data production of maggots was observed by measuring the weight of the maggots produced in the media in each treatment and $10 \mathrm{gs}$ of maggots samples were taken to count the number of individuals. Maggots length was measured using a ruler at the end of the study by taking 10 samples from each treatment randomly. The conversion value and medium efficiency (bioconversion) were by comparing the amount of maggots produced with the number of substrates used. Observation of nutrient content in maggots by conducting proximate analysis includes water content, ash content, fat content, protein content, and carbohydrates contained in maggots. The bioconversion of organic substrate medium is calculated by the ratio of substrate medium to maggots production, namely substrate absorption efficiency (ASE) and bioconversion ratio rate (BcRR). Proximate analysis was carried out at Jambi University's Animal Husbandry Laboratory. To see the efficiency of the organic waste used, it was calculated using the economic conversion ratio (ECR), which was a comparison of the costs incurred to produce maggots with production results.

\section{Data analysis}

The data obtained were tabulated with Microsoft Office Excel 2013 and analyzed for variance using the SPSS 22. This analysis was

Table 1. Composition of the proximate value of maggots substrates Hermetia illucens in palm kernel meal, coconut meal, and cabbage vegetable waste.

\begin{tabular}{cccccccc}
\hline \multirow{2}{*}{ Treatment } & \multicolumn{3}{c}{ Medium material (\%) } & \multicolumn{5}{c}{ Proximate (\%) } \\
\cline { 2 - 8 } & PKM & CM & CVW & P & C & F & A \\
\hline A & 100 & 0 & 0 & 15.98 & 30.76 & 10.35 & 3.69 \\
B & 50 & 50 & 0 & 14.88 & 24.21 & 7.66 & 3.25 \\
C & 50 & 0 & 50 & 8.54 & 24.04 & 17.09 & 2.75 \\
D & 50 & 25 & 25 & 9.90 & 23.63 & 14.86 & 3.10 \\
\hline
\end{tabular}

$\overline{\mathrm{PKM}}=$ palm kernel meal, $\mathrm{CW}=$ coconut waste, $\mathrm{CVW}=$ cabbage vegetable waste, $\mathrm{P}=$ protein, $\mathrm{C}=$ carbohydrate, $\mathrm{F}=$ fat, and $\mathrm{A}=$ ash 
applied to determine the effect of treatment on each parameter tested at a $95 \%$ confidence level. If there was a significant difference, then it would be continued with the LSD test to see the difference between treatments. Other data to support the research would be analyzed descriptively.

\section{RESULTS AND DISCUSSION}

\section{Result}

\section{Maggots biomass}

Maggots biomass was represented by two parameters, namely the average biomass of maggots per $4 \mathrm{~kg}$ of media and the average weight of maggots in $\mathrm{g}$ per individual. Based on the results of statistical tests, there were differences in the average biomass between treatments, the highest maggots biomass was in treatment $\mathrm{A}$ ( $100 \%$ oil palm waste) of $673.67 \mathrm{~g} / 4 \mathrm{~kg}$ of media, this result was as good as treatments B and C. While the lowest maggots biomass was found in treatment $\mathrm{D}(50 \%$ oil palm waste $+25 \%$ coconut waste $+25 \%$ cabbage waste) was $239.67 \mathrm{~g} / 4 \mathrm{~kg}$ of media. The results are presented in Table 2 as follows.

\section{Average length}

The average maggots length measured during the study was presented in Table 3 below. The results showed that there was no difference $(P>0.05)$ between treatments on the average length of the maggots. The average maggots length for each treatment was A $(1.83 \mathrm{~cm}), \mathrm{B}(1.58 \mathrm{~cm}), \mathrm{C}$ $(1.67 \mathrm{~cm})$, and $\mathrm{D}(1.70 \mathrm{~cm})$.

\section{Amount of maggots}

In addition to measuring the biomass, average weight, and length of maggots, measurements were also made of the number of individual maggots during the study. The results of the study are presented in Table 4 as follows. Based on the results of statistical tests showed that there was a difference $(\mathrm{P}<0.05)$ between treatments. The highest amount of maggots was found in treatment B (50\% PKM + 50\% cabbage waste), the lowest amount of maggots was found in D treatment $(50 \% \mathrm{PKM}+25 \%$ coconut waste $+25 \%$ cabbage vegetable waste).

\section{Maggots bioconversion}

This bioconversion is a form of changing organic elements from waste (substrate)

Table 2. Average biomass and weight of maggots, Hermetia illucens on palm kernel meal, coconut waste, and cabbage vegetable waste.

\begin{tabular}{|c|c|c|c|c|c|}
\hline \multirow{2}{*}{ Treatment } & \multicolumn{3}{|c|}{ Medium materials (\%) } & \multirow{2}{*}{$\begin{array}{c}\text { Average maggots biomass } \\
\text { (g/4 kg substrates) }\end{array}$} & \multirow{2}{*}{$\begin{array}{l}\text { Average maggots weight } \\
(\mathrm{g} / \text { individual })\end{array}$} \\
\hline & PKM & $\mathrm{CC}$ & CVW & & \\
\hline A & 100 & 0 & 0 & $673.67^{\mathrm{a}}$ & 0.20 \\
\hline B & 50 & 50 & 0 & $606.33^{\mathrm{a}}$ & 0.12 \\
\hline $\mathrm{C}$ & 50 & 0 & 50 & $513.00^{\mathrm{a}}$ & 0.16 \\
\hline $\mathrm{D}$ & 50 & 25 & 25 & $239.67^{b}$ & 0.16 \\
\hline \multicolumn{4}{|c|}{ Total average } & 508.17 & 0.161 \\
\hline
\end{tabular}

$\overline{\mathrm{PKM}}=$ Palm kernel meal, $\mathrm{CW}=$ coconut waste, $\mathrm{CVW}=$ cabbage vegetable waste. Different letters in different columns showed significant different $(\mathrm{P}<0.05)$

Table 3. The average length of maggots, Hermetia illucens on palm kernel meal, coconut waste, and cabbage vegetable waste.

\begin{tabular}{|c|c|c|c|c|}
\hline \multirow{2}{*}{ Treatment } & \multicolumn{3}{|c|}{ Medium materials $(\%)$} & \multirow{2}{*}{$\begin{array}{l}\text { Length average maggots } \\
(\mathrm{cm} / \text { individual })\end{array}$} \\
\hline & PKM & $\mathrm{CC}$ & CVW & \\
\hline A & 100 & 0 & 0 & $1.83^{\mathrm{a}}$ \\
\hline B & 50 & 50 & 0 & $1.58^{\mathrm{a}}$ \\
\hline $\mathrm{C}$ & 50 & 0 & 50 & $1.67^{\mathrm{a}}$ \\
\hline $\mathrm{D}$ & 50 & 25 & 25 & $1.71^{\mathrm{a}}$ \\
\hline \multicolumn{4}{|c|}{ Total average } & 1.70 \\
\hline
\end{tabular}

$\overline{\mathrm{PKM}}=$ Palm kernel meal, $\mathrm{CW}=$ coconut waste, $\mathrm{CVW}=$ cabbage vegetable waste. Different letters in different columns showed significant different $(\mathrm{P}<0.05)$ 
to maggots which is measured using the parameters of substrate absorption efficiency and the bioconversion ratio rate from the use of substrate from palm kernel waste, cabbage waste, and coconut waste combined as much as $4 \mathrm{~kg}$. Substrate absorption efficiency (SAE) and Bioconversion ratio (BRR) in the utilization of organic substrates by maggots are presented in Figure 1 below.

Based on the picture above, it can be seen that the best SAE was found in treatment A (16.83\%) followed by treatment B $(16.82 \%)$, treatment C $(11.41 \%)$. The lowest SAE was found in treatment $\mathrm{D}$ which was equal to $(5.99 \%)$. The results of this study showed that PKM combined with other materials showed a decrease in substrate absorption efficiency. This result is inversely related to the BRR. The best level of BRR was found in treatment $\mathrm{D}(16.74 \%)$ followed by treatment $\mathrm{C}(7.80 \%)$, treatment $\mathrm{D}(6.60 \%)$. The lowest level of BRR is found in treatment $\mathrm{A}$, which is equal to $(5.94 \%)$. There is an increase in the rate of bioconversion ratio when PKM is combined with other materials.

\section{Profil of proximate maggots}

The cultured BSF maggots at the end of the study was analyzed for its proximate profile to see the nutritional content of the BSF maggots. The results of the proximate profile analysis are presented in Table 5 below. The results of the analysis showed that there were differences in the results of the nutritional content of each treatment. The difference is in the protein content. The highest protein content was found in treatment A at $46.50 \%$, followed by treatment C $38.10 \%$,

Table 4. The average amount of maggots, Hermetia illucens on palm kernel meal, coconut waste, and cabbage vegetable waste.

\begin{tabular}{ccccc}
\hline \multirow{2}{*}{ Treatment } & \multicolumn{3}{c}{ Medium materials (\%) } & \multirow{2}{*}{ Amount maggots average (individual) } \\
\cline { 2 - 4 } & PKM & CC & CVW & $3.437,09^{\mathrm{a}}$ \\
A & 100 & 0 & 0 & $5.182,31^{\mathrm{b}}$ \\
$\mathrm{B}$ & 50 & 50 & 0 & $3.309,68^{\mathrm{a}}$ \\
$\mathrm{D}$ & 50 & 0 & 50 & $1.479,44^{\mathrm{c}}$ \\
\hline & 50 & 25 & 25 & $13.308,52$ \\
\hline
\end{tabular}

$\mathrm{PKM}=$ palm kernel meal, $\mathrm{CC}=$ coconut waste, $\mathrm{CSW}=$ cabbage vegetable waste. Different letters in different columns showed significant different $(\mathrm{P}<0.05)$

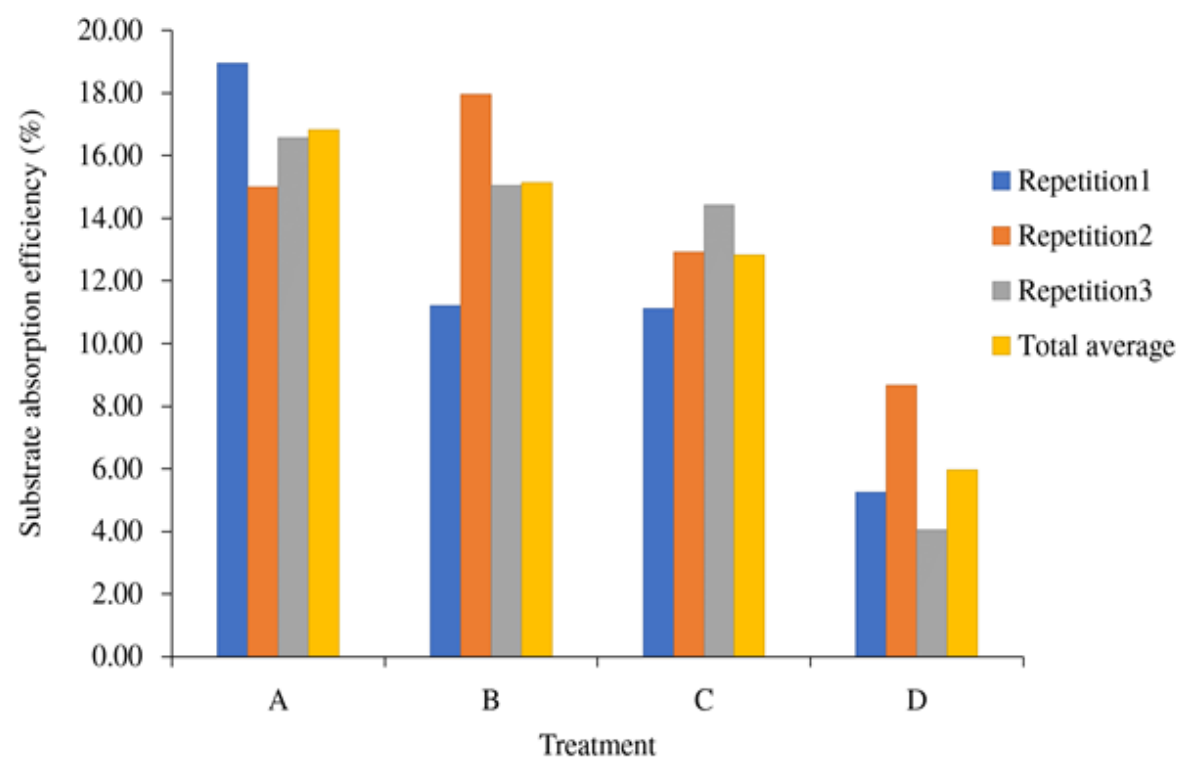

Figure 1. The average percentage SAE and BRR from bioconversion in organic substrates by maggots produced on each treatment for 21 days of the experiment. A: $100 \%$ PKM, B: $50 \% \mathrm{PKM}+50 \% \mathrm{CW}, \quad \mathrm{C}: 50 \% \mathrm{PKM}+\mathrm{CSW}$, and D: $\mathrm{P} 50 \% \mathrm{PKM}+25 \% \mathrm{CC}+25 \% \mathrm{CSW} . \mathrm{PKM}=$ palm kernel meal, $\mathrm{CW}=$ coconut waste, $\mathrm{CVW}=$ cabbage vegetable waste. 
treatment B $35.90 \%$. The lowest protein content was found in treatment $\mathrm{D}$, which was $22.30 \%$. Carbohydrate, fat, and ash content in this study ranged from $5.80-22.40 \%, 36.90-46.60 \%$, and $8.10-9.30 \%$, respectively.

\section{Economic analysis}

Economic analysis of maggots cultivation production using an organic waste substrate with PKM medium combined with coconut waste and treated cabbage vegetable waste can be seen in Table 6 below. The results of the economic analysis showed that the production cost of maggots using the PKM+Cabbage vegetable waste medium (Rp.7.257) was lower than the other mediums in treatment A, C, and D, each of which was Rp. 11,875, Rp. 8,577 and Rp. 18.359 per $\mathrm{kg}$, as well as the ECR (economic conversion ratio) value in treatment $\mathrm{B}$ (PKM + vegetable cabbage waste), resulted in an ECR value of 5.805; lower than the other treatments, namely $\mathrm{PKM}+$ coconut waste+cabbage vegetable waste (D) of 14.687, PKM+coconut meal (C) of 6.862 and PKM (D) of 9.

\section{Discussion}

Maggots production is strongly influenced by the substrate or growing media (Odjo et al., 2018). In a long period, many research results have reported the efficiency level of several types of substrates in maggots production (Odjo et al., 2018). The productivity of the utilization of these substrates varies greatly depending on their function and nature (Djissou et al., 2015). The results of maggots production showed that the best maggots biomass was in treatment $\mathrm{A}$ of 673.67 $(0.20) \mathrm{g}$, followed by treatment B of $606.33(0.12)$ $\mathrm{g}$, treatment $\mathrm{C}$ of $513.00(0.16) \mathrm{g}$, and the lowest was in treatment D of $239.69(0.16) \mathrm{g}$ (Table 2). Based on analysis of variance, treatments $A$, $\mathrm{B}$, and $\mathrm{C}$ were relatively great and significantly different from treatment $\mathrm{D}$. This was because the composition of the media in treatments $\mathrm{A}, \mathrm{B}$, and $\mathrm{C}$ were able to meet the nutritional needs for the growth of BSF larvae. In media A, B, and C, it was estimated that the nutritional content was relatively sufficient and balanced to stimulate the growth of the maggots. Good organic matter for maggots growth is a material that must contain

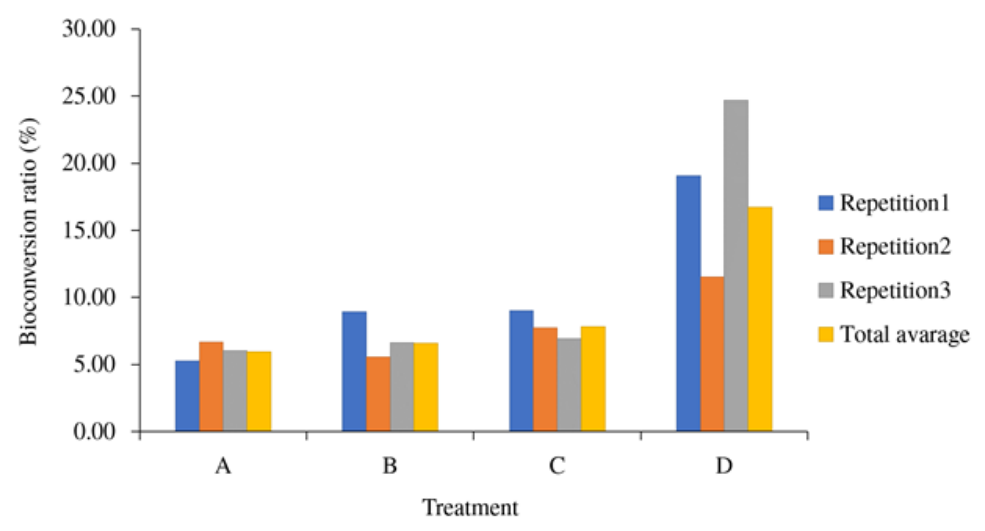

[Continue] Figure 1. The average percentage SAE and BRR from bioconversion in organic substrates by maggots produced on each treatment for 21 days of the experiment. A: $100 \%$ PKM, B: $50 \%$ PKM + 50\% CW, C: $50 \%$ $\mathrm{PKM}+\mathrm{CSW}$, and D: P 50\% PKM + 25\% CC + 25\% CSW. PKM = palm kernel meal, CW= coconut waste, CVW = cabbage vegetable waste.

Table 5. The average value of the composition of the proximate maggots Hermetia illucens in the medium of palm kernel meal, coconut waste, and cabbage vegetable waste

\begin{tabular}{cccccccc}
\hline \multirow{2}{*}{ Treatments } & \multicolumn{3}{c}{ Medium materials (\%) } & \multicolumn{5}{c}{ Maggots proximate (\%) } \\
\cline { 2 - 8 } & PKM & CM & CVW & P & C & F & A \\
\hline A & 100 & 0 & 0 & 46.50 & 7.30 & 36.90 & 9.30 \\
B & 50 & 50 & 0 & 35.90 & 13.40 & 41.90 & 8.80 \\
C & 50 & 0 & 50 & 38.10 & 5.80 & 47.90 & 8.10 \\
D & 50 & 25 & 25 & 22.30 & 22.40 & 46.60 & 8.7
\end{tabular}

$\overline{\mathrm{PKM}}=$ palm kernel meal, $\mathrm{CM}=$ coconut meal, $\mathrm{CVW}=$ cabbage vegetable waste, $\mathrm{P}=$ protein, $\mathrm{C}=$ carbohydrate, $\mathrm{F}$ $=$ fat, $\mathrm{A}=\mathrm{ash}$ 
a lot of nutritional elements, especially organic matter. This product was in line with the results of research by Syahrizal et al. (2014) that PKM used as media for maggots maintenance resulted in higher maggots production $(0.18 \pm 0.68 \mathrm{~g} /$ individual) than the combination of PKM with tofu waste $(0.17 \pm 0.68$ and $0.16 \pm 0.68 \mathrm{~g} /$ individual). Monita et al. (2017) explained that BSF larvae have body weights ranging from $0.09-0.11 \mathrm{mg}$. According to Cicilia and Susila (2021), the average weight of maggots produced by this media composition was $0.30 \mathrm{~g} / \mathrm{head}$. This relationship also appeared to be linear with a high proximate value of protein medium which is directly proportional to maggots production in PKM medium. Whereas, the results of proximate protein in PKM (15.98\%) and followed by coconut waste $(14.88 \%)$, cabbage waste $(8.54 \%)$, and a combination of $9.90 \%$ are presented in Table 5 .

The results of the measurement of the average length of the maggots in each treatment obtained results for treatment A of $1.83 \mathrm{~cm}$, treatment B of $1.58 \mathrm{~cm}$, treatment $C$ of $1.67 \mathrm{~cm}$, and treatment D of $1.70 \mathrm{~cm}$ (Table 3). This was not significantly different between treatments $(\mathrm{P}>0.05)$. Maggots production appears linear with bioconversion of nutrient material obtained from the treatment medium in the form of proximate Table 1 such as protein, carbohydrates, fat, and ash media, respectively oil palm waste $(15.98 \%, 30.76 \%$, $10.35 \%$, and $3.369 \%$ ), followed by coconut waste $(14.88 \%, 24.21 \%, 7.66 \%$, and $3.25 \%)$, cabbage waste $(8.54 \%, 24.04 \%, 17.09$ and $2.75 \%)$ and combinations $(9.90 \%, 23.63 \%, 14.86 \%$, and $3.10 \%)$. According to Syahrizal et al. (2014) that maggots aged 3-4 weeks reared using PKM media have a length ranging from 1.8 to $2.30 \mathrm{~cm}$. Monita et al. (2017) said that BSF larvae ranged in length from $15.85-16.44 \mathrm{~mm}$.

The highest number of maggots was found in treatment $\mathrm{B}$ and the lowest in treatment $\mathrm{D}$. The high number of maggots in treatment $B$ was thought to be caused by their relatively small size when compared to $\mathrm{A}, \mathrm{C}$, and $\mathrm{D}$ and the late arrival of BSF maggots to the organic medium. Treatment D, which had fewer than 1,479.44 tails, was caused by suboptimal nutritional elements and insufficient aroma that could bring BSF as an attractant for laying eggs. According to Gold et al. (2018) that for the performance process of organic waste heat is needed for inactivation and safety. In addition, oxygen and $\mathrm{pH}$ are needed in the intestinal environment because they affect food decomposition, enzyme activity and form the number and diversity of microbes. Tomberlin et al. (2009) explained that the black army fly Hermetia illucens was reared on a wheat diet at 27,30 , and $36^{\circ} \mathrm{C}$. Survival of 4-to-6-day old larvae to adults averages $74-97 \%$ at 27 and $30^{\circ} \mathrm{C}$ but only $0.1 \%$ at $36^{\circ} \mathrm{C}$. Flies require an average of 4 days (11\%) longer to complete larval and pupal development at $27^{\circ} \mathrm{C}$ than at $30^{\circ} \mathrm{C}$. At 27 and $30^{\circ} \mathrm{C}$, females weigh on average $17-19 \%$ more than males but require an average of 0.60.8 days $(3.0-4.3 \%)$ longer to complete larval development. Azir et al. (2017) explained that the high production of maggots from green flies Chrysomya megachepala for laying eggs because the organic medium provides a distinctive aroma and is easily decomposed by maggots.

Tabel 6. Economic analysis of BSF maggots with organic waste substrate media combined for one cycle of 21 days of the maintenance period.

\begin{tabular}{lcccc}
\hline \multicolumn{1}{c}{ Parameter } & \multicolumn{3}{c}{ Treatment } \\
\cline { 2 - 5 } & $\mathrm{A}$ & $\mathrm{B}$ & $\mathrm{C}$ & $\mathrm{D}$ \\
\hline Amount of medium (kg) & 4.00 & 4.00 & 4,00 & 4,00 \\
Amount of maggots produced (kg) & 0.674 & 0.606 & 0,513 & 0,240 \\
Media price (per kg)* & 8.000 & 4.400 & 4.400 & 4.400 \\
Maggots price (Rp/kg) & 5.000 & 5.000 & 5.000 & 5.000 \\
SAE (substrate absorption efficiency)\%** & 16.84 & 15.16 & 12,83 & 5,99 \\
Production cost (Rp/kg maggots)*** & 11.875 & 7.257 & 8.577 & 18.359 \\
Economic conversion ratio (ECR)**** & 9,500 & 5,805 & 6,862 & 14,687 \\
\hline
\end{tabular}

* PKM price Rp 2,000/kg, Coconut dregs Rp 200/kg, cabbage vegetable waste Rp 200/kg

$* *$ Maggots conversion $=$ number of maggots generated/number of media $\times 100 \%$

$* * *$ Maggots production cost $=$ media price $/$ amount of maggots produced

$* * * * \mathrm{ECR}=($ Number of medium $\times$ medium price $) /($ maggots production $\times$ maggots selling price $)$

$\mathrm{PKM}=$ palm kernel meal, $\mathrm{CC}=$ coconut waste, $\mathrm{CVW}=$ cabbage vegetable waste 
Overall, the experimental results of media bioconversion to maggots were relatively great. Azir et al. (2017) explained that the yield of fish waste was $8.2347 \%$ and the best material was the combination of $50 \%$ fish waste with $19.16 \%$ coconut pulp. According to Pathiassana et al. (2020), the average value of bioconversion (substrate consumption) of maggots in carrots and radishes were $48.42 \%$ boiled and $57.9 \%$ fermented. The best substrate bioconversion used by the development of maggots production occurred in treatments A (16.84 \%), and B (16.82 $\%$ ), while in treatments $\mathrm{C}(11.41 \%)$ and $\mathrm{D}(5.99 \%)$ were lower, this was related to the requirement and availability of protein for maggots as the main nutritional element. High and low bioconversion were consequences of retention of absorption of protein and other nutritional elements in the form of carbohydrates, fats, minerals, and environmental factors available in maggots living substrate medium. In addition to organic matter which is aromatic and easily decomposed, BSF may be attracted to the nutrients and water content of the substrate medium. Surendra et al. (2020) explained that in increasing the biomass of larvae or pupae, BSF utilized more mechanical and automatic system to produce bioactive compounds, such as antimicrobial peptides, medium-chain fatty acids, and chitin, as well as their derivatives. Indariyanti and Barades (2018) explained that maggots Hermetia illucens was an organism that consumes organic material which contained anti-microbial and anti-fungal properties so that it did not carry disease agents.

The composition of the BSF maggots proximate test results Hermetia illucens which was developed on a medium has given oil palm meal, coconut meal, and cabbage vegetable waste showed that there were differences in the results of the nutritional content of each treatment. On the contrary, the protein content between treatment A was $46.5 \%$, treatment B was $35 \%$, treatment $\mathrm{C}$ was $38 \%$, and treatment $\mathrm{D}$ was $22 \%$ (Table 5). The carbohydrate content was different amongst $\mathrm{A}$ and $\mathrm{B}, \mathrm{C}$, and $\mathrm{D}$. The fat content was also different in treatments $\mathrm{A}$ and $\mathrm{B}$ with $\mathrm{C}$ and $\mathrm{D}$, while the mineral elements (ash) were relatively similar amongst treatments. The difference in the composition of the nutritional elements of maggots might be related to lifestyle and the composition of the elements of the maggots medium. Indariyanti and Barades (2018), stated that maggots biomass was 435.2 , protein content was $44.58 \%$, fat was $4.89 \%$, crude fiber was $8.02 \%$, linolenic acid was
1.98, and linoleic acid was 3.67. Fauzi and Sari (2018) explained that maggots is a type of natural feed that has high protein containing 41-42\% crude protein, 31-35\% ether extract, $14-15 \%$ ash, $4.8-5.1 \%$ calcium, and $0.6-0.63 \%$ phosphorus for dry weight. Fahmi et al. (2007) explained that maggots contains about 32.31-60.2\% protein and quite high fat around 9.45-13.3\% depending on the age and quality of the substrate. Monita et al. (2017) explained that BSF larvae had a protein content of $33.31-33.88 \%$ and a fat content of $30.07-34.39 \%$. The high production and protein maggots in the PKM medium in this study was thought to be due to the aroma attractant factor and the adequacy of the nutritional and water elements needed for BSF life needs compared to other organic mediums. According to Rachmawati et al. (2010) that the level of maggots protein in PKM media aged 5 days was $61.42 \%$. higher than day $20(42.07 \%)$. Cicilia and Susila (2021) explained that fresh maggots protein was $9.11 \%$; water $73.69 \%$ and in the form of flour $31.30 \%$; $0.79 \%$ water, $17.11 \%$ fresh fat, and $34.36 \%$ flour. According to Gold et al. (2018) that larval BSF biomass contains $32-58 \%$ proteins and $15-39 \%$ lipids. The better the medium protein content and the faster the maggots was produced, the higher the maggots protein content will be (Suciati \& Faruq, 2017).

The results of economic analysis of maggots cultivation production using an organic waste substrate with PKM medium combined with coconut waste and cabbage waste shows that the production cost of maggots using PKM medium + cabbage waste is Rp 7,257 lower than other mediums in treatments A, C, and D. Each of which is $\mathrm{Rp} 11,875, \mathrm{Rp} 8,577$ and $\mathrm{Rp} 18,359$ per $\mathrm{kg}$, as well as the ECR (economic conversion ratio) value in treatment $\mathrm{B}$ (PKM + vegetable cabbage waste), resulted in an ECR value of 5.805; lower than the other treatments, namely PKM + coconut waste+cabbage vegetable waste (D) of 14,687, PKM + coconut meal (C) of 6.862 and PKM (D) of 9,500. Rachmawati et al. (2010) explained the results of research conducted in the field, it is known that to obtain $1 \mathrm{~kg}$ of fresh $H$. illucens larvae take $3 \mathrm{~kg}$ of PKM. To obtain 1 $\mathrm{kg}$ of dry H. illucens larvae (raw feed material) required $3 \mathrm{~kg}$ of fresh $H$. illucens larvae (water content $63,72 \%$ ). Production of H. illucens larvae in Sungai Gelam Jambi, it was known that the price of $H$. illucens larvae-based pellets produced is only Rp 3,500.00 per kilo (PKM price is Rp $200.00 / \mathrm{kg}$ ), cheaper than the price of commercial pellets, which is $\operatorname{Rp} 7,000.00$ per kilo. 


\section{CONCLUSION}

The best maggots production was found in treatments A (100\% PKM) with biomass of $673.67 \mathrm{~g} / 4 \mathrm{~kg}$ medium, and $0.20 \mathrm{~g} /$ individual) and B $(50 \%$ PKM $+50 \%$ CVW) with total maggots $(5,182.31$ in. $/ 4 \mathrm{~kg}$ medium $)$. The best organic medium bioconversion in maggots production was found in treatments A $(16.84 \%)$, and B $(16.82 \%)$ with proximate proteins A $(46.5 \%)$ and $\mathrm{B}(35 \%)$. The cost of producing maggots with PKM+CVW media $(\operatorname{Rp} 7,257)$ is relatively cheaper in succession than other media (A, C, and D), which is Rp 11,875, Rp. 8,577 and Rp 18,359 per $\mathrm{kg}$, with the ECR value of PKM + CVW was 5.805 .

\section{REFERENCES}

Adéyèmi $\mathrm{AD}$, Adéchola $\mathrm{P}$, Kayodé $\mathrm{P}$, Chabi IB, Oloudé B. Odouaro O, Martinus JR, Nout, Linnemann AR. 2020. Screening local feed ingredients of benin, West Africa, for fish feed formulation. Aquaculture Reports 17: 1-7.

Arifin MZ, Widodo A, Fauziah A, Aonullah AA, Halim AM, Cahyanuran AM. 2020. Meal substitution on growth and health status of tilapia Oreochromis niloticus. Jurnal Chanos chanos 18: 83-91.

Azhari, Nasution TI, A Hilman A, Ritonga SI, Pangestu I. 2020. Improvement of the composition value of commercial fish feeds with additional waste of torpedo scad fish scales, water hyacinth, and taro leaves. International Conference on Agriculture, Environment and Food Security 782: 1-7

Azir A, Harris H, Haris RBK. 2017. Produksi dan kandungan nutrisi maggots Chrysomya megacephala menggunakan komposisi media kultur berbeda. Jurnal Ilmu-ilmu Perikanan dan Budidaya Perairan 12: 34-40.

Baki B, Yücel Ş. 2017. Feed cost/production income analysis of seabass Dicentrarchus labrax aquaculture. International Journal of Ecosystems and Ecology Sciences 7: 859-864.

Cahya MD, Andriani Y, Junianto. 2021. Utilization of food waste as raw material for fish feed (a review). Global Scientific Journals 9: 435-439.

Cicilia AP, Susila N. 2021. Potensi ampas tahu terhadap produksi maggots Hermetia illucens sebagai sumber protein pakan ikan. Anterior Jurnal 20: 40-47.

Cummins VC, Cummins Jr, Steven D, Rawles
Kenneth R, Thompson, Velasquez A, Kobayashi K, Hager J, Webster CD. 2017. Evaluation of black soldier fly Hermetia illucens larvae meal as partial or total replacement of marine fish meal in practical diets for Pacific white shrimp Litopenaeus vannamei. Journal of Aquaculture 473: 337-344.

Fahmi MR, Hem S, Subamia IW. 2007. Potensi maggots sebagai salah satu sumber protein pakan ikan. Dalam: Dukungan Teknologi untuk Meningkatkan Produk Pangan Hewan dalam Rangka Pemenuhan Gizi Masyarakat. Prosiding Seminar Nasional Hari Pangan Sedunia XXVII. Bogor: Puslitbangnak. pg 125-130.

Fahmi MR, Hem S, Subamia IW. 2009. Potensi maggot untuk peningkatan pertumbuhan dan status kesehatan ikan. Jurnal Riset Akuakultur 4: 221-232.

Fauzi, RUA, Sari ERN. 2018. Analisis usaha budidaya maggot sebagai alternatif pakan lele. Industria: Jurnal Teknologi dan Manajemen Agroindustri 7: 39-46.

Fika MPW, Suwandari A, Hartad R. 2016. Analysis of financial feasibility and contribution to income household income farmer fish catfish dumbo. Agritrop Jurnal Ilmu-Ilmu Pertanian 14: 199-207.

Gold MJK, Tomberlin S, Diener C, Zurbrügg A, Mathys. 2018. Decomposition of biowaste macronutrients, microbes, and chemicals in black soldier fly larval treatment. Waste Management Journal 303-307.

Herawati VE, Pinandoyo, Windarto S, Hariyadi P, Hutabarat J, Darmanto YS, Rismaningsih N, Prayitno SB, Radjasa OK. 2020. Maggot meal Hermetia illucens substitution on fish meal to growth performance, and nutrient content of milkfish Chanos chanos. HAYATI Journal of Biosciences 27: 154-165

Indariyanti N, Barades E. 2018. Biomass evaluation and maggot nutrition content Hermetia illucens on different cultivation media. Prosiding Seminar Nasional Pengembangan. Teknologi Pertanian Politeknik Negeri Lampung. 137-141.

Izmaniar H, Mahyudin I, Agusliani E, Ahmadi. 2018. The business prospect of climbing perch fish farming with biofloc technology at De' Papuyu farm Banjarbaru. International Journal of Environment, Agriculture and Biotechnology 3: 1145-1153.

Lardé, G. 1990. Recycling of coffee pulp by 
Hermetia illucens (Diptera: Stratiomyidae) larvae. Biological Wastes 33: 307-310.

Leong, SY, Kutty SRM, Malakahmad A, Tan CK. 2016. Feasibility study ofbiodiesel production using lipids of Hermetia illucens larva fed with organic waste. Waste Manage 47: 84-90.

Lestari A, Wahyuni TH, Mirwandhono E, Ginting N. 2020. Maggot black soldier fly Hermetia illucens nutritional content using various culture media. Jurnal Peternakan Integratif 8: 202-211.

Liu C, Wang C, Yao H. 2019. Comprehensive resource utilization of waste using the black soldier fly Hermetia illucens (L.) diptera: stratiomyidae. Animals 9: 83-90.

Mokolensang JF, Hariawan MGV, Manu L. 2018. Maggot Hermetia illunces sebagai pakan alternatif pada budidaya ikan. Jurnal Budidaya Perairan 6: 32-37.

Monita SH, Sutjahjo AA, Amin MR, Fahmi. 2017. Pengolahan sampah organik perkotaan menggunakan larva black soldier fly Hermetia illucens. Jurnal Pengelolaan Sumberdaya Alam dan Lingkungan 7: 227-234.

Newton, L, Sheppard C, Watson DW, Burtle G, Dove R. 2005. Using the black soldier fly, Hermetia illucens, as a value-added tool for the management of swine manure. US: North Carolina State University, Raleigh.

Nguyen TT, Tomberlin JK, Vanlaerhoven S. 2015. Ability of black soldier fly (Diptera: Stratiomyidae) larvae to recycle food waste. Environmental Entomology 44: 406-410.

Odjo NI, Djissou SMA, Guezo C, Fiogbe DE. 2018. Optimization of maggot production from a mixture of chicken viscera and soya cake based on different ratios. International Journal of Biological and Chemical Sciences 12: 1583-1589.

Pathiassana MTS, IzzyN, Haryandi S, Nealma. 2020. Studi laju umpan pada proses biokonversi dengan variasi jenis sampah yang dikelola PT. Biomagg sinergi internasional menggunakan larva black soldier fly Hermetia illucens. Jurnal Tambora 4: 86-95.
Rachmawati, Buchori D, Hidayat P, Hem S, Fahmi MR. 2010. Perkembangan dan kandungan nutrisi larva Hermetia illucens (Linnaeus) (Diptera: Stratiomyidae) pada bungkil kelapa sawit. Jurnal Entomologi Indonesia 7: 28-41.

Rizki S, Hartami P, Erlangga. 2017. The level of population density maggot on different growth media. Acta Aquatica 4: 21-25.

Rui M, Sánchez-López A, Leal RS, MartínezLlorens S, Oliva-Teles A, Peres H. 2017. Black soldier fly Hermetia illucens pre-pupae meal as a fish meal replacement in diets for european seabass Dicentrarchus labrax. Aquaculture 476: 79-85.

Suciati R, Faruq H. 2017. Efektifitas media pertumbuhan maggot, Hermetia illucens (lalat tentara hitam) sebagai solusi pemanfaatan sampah organik. Biosfer. Jurnal Pendidikan Biologi 2: 8-13.

Surendra KC, Tomberlin JK, Huis AV, Cammack JA, Heckmann LL, Khanal SK. 2020. Rethinking organic wastes bioconversion: Evaluating the potential of the black soldier fly Hermetia illucens (L.) (Diptera: Stratiomyidae) (BSF). Waste Management 117: 58-80.

Syahrizal, Ediwarman M. Ridwan. 2014. Kombinas ilimbah kelapa sawit dan bungkil tahu sebagai media budidaya maggot Hermetia illucens salah satu alternatip pakan ikan. Jurnal Ilmiah Universitas Batanghari Jambi 14: 108-113.

Tomberlin JK, Adler PH, Myers HM. 2009. Development of the black soldier fly (Diptera: Stratiomyidae) in relation to temperature. Environmental Entomolog 38: 930-934.

Tschirner M, Simon A. 2015. Influence of different growing substrates and processing on the nutrient composition of black soldier fly larvae destined for animal feed. Journal of Insects as Food and Feed 1: 1-12.

Tugiyono, Febryano IG, Puja Y, Suharso. 2020. Utilization of fish waste as fish feed material as an alternative effort to reduce and use waste. Pakistan Journal of Biological Sciences 23: 701-707. 